\section{Survival and Yields of Fall-planted Winter Sprouting Broccoli Grown in High Tunnels for Spring Harvest in the Northeastern United States}

\author{
Clifton A. Martin ${ }^{1,2}$ and Rebecca Grube Sideman ${ }^{2,3}$
}

\begin{abstract}
ADDITIONAL INDEX WORDS. rowcover, season extension, unheated high tunnel
SUMMARY. Winter sprouting broccoli [WSB (Brassica olevacea var. italica)] is a biennial crop that is typically planted in the fall and harvested in the spring in the United Kingdom. To evaluate their suitability as an early spring crop in the northeastern United States, 10 cultivars of WSB were grown in replicated experiments inside an unheated high tunnel over 2 years in Durham, NH. Results showed that the use of a secondary low tunnel covered with heavy rowcover $\left(1.25 \mathrm{oz} / \mathrm{yard}^{2}\right)$ significantly increased winter survival, yields, and earliness of all WSB cultivars. Cultivars differed in terms of days to maturity, yields, and shoot quality. For September planting dates, broccoli shoots were harvested from March to early May. Across cultivars, days to harvest range from 190 to 216 days in 2008-09, and from 209 to 238 days in 2009-10. Season-long yields ranged from 150 to $238 \mathrm{~g}$ /plant. The cultivars, Santee, Red Spear, White Sprouting Early, and Late White Star, were among the highest yielding cultivars that produced attractive and tender shoots, spanning the entire harvest season. Our experiments established that fall plantings of WSB may be overwintered in an unheated high tunnel for a spring harvest in USDA Hardiness Zone $\mathbf{5}$ sites.
\end{abstract}

I $\mathrm{n}$ the northeastern United States, increased interest in season extension combined with high demand for fresh vegetables in spring provides a possible market for hardy overwintering fresh market vegetables. In Great Britain, WSB is a biennial crop that is planted in late summer, overwinters, and is harvested in winter and early spring. In this report, we explore the potential for WSB production as a new crop for early spring production in New England.

The term "broccoli" is used to describe a wide array of types of cultivated accessions of Brassica oleracea. Broccolis may be "sprouting" or "heading," depending on the degree of branching exhibited and the size of the inflorescences. Further, accessions vary in sepal color (green, purple, and white) and

Partial funding was provided by the New Hampshire Agricultural Experiment Station. This is Scientific Contribution Number 2469

We thank John McLean, Evan Ford, and David Goudreault for technical assistance. We also thank Dr. Cathy Neal for providing thoughtful reviews of the draft manuscript.

\section{${ }^{1}$ OARDC, 1680 Madison Avenue, Wooster, OH}

${ }^{2}$ Department of Biological Sciences, University of New Hampshire, 38 Academic Way, Durham, NH, 03824

${ }^{3}$ Corresponding author. E-mail: becky.sideman@unh. edu. life cycle (annual, biennial, and perennial) (Gray, 1989; Whealy, 2004).

In the United States, annual green heading broccoli (B. oleracea var. ital$i c a)$, known as calabrese in Europe, is widely grown. In the 1980s, calabrese was the only $B$. oleracea var. italica vegetable to be extensively developed by crop breeding and to be represented by numerous cultivars including both open-pollinated and $\mathrm{F}_{1}$ hybrid cultivars (Gray, 1989). It has been selected for rapid maturity, an annual habit, increased head size, and a decrease in lateral shoot development. The crop is now recognized as a heading vegetable rather than a sprouting vegetable (Crisp and Gray, 1985). These characteristics distinguish calabrese from the purple- and white-sprouting broccolis that are biennial in habit, are cultivated for lateral shoot development, and bear white, yellow, or green cauliflower curds or clusters of young flower buds whose sepals may be green or purple (Gray, 1989).

Annual sprouting brassicas currently grown in the United States include broccoli raab (Brassica rapa ssp. rapa) and broccolini, a cross between heading broccoli and chinese kale or gai-lan (Brassica alboglabra) (Cintas et al., 2002; Livingston, 2010). The former has a pungent mustard green flavor, and the latter is proprietary and not available for independent market gardeners to grow (Livingston, 2010). By contrast, the mild-flavored WSB (B. oleracea var. italica) is a biennial crop that is popular in Great Britain, but relatively unknown in the United States.

While peer-reviewed literature is widely available specific to heading broccoli, there is very little that specifically addresses WSB. The sprouting broccolis are documented in writings from the 16th century when, according to Nieuwof (1969), Delachamp described sprouting broccoli under the name Brassica asparagoides. Miller's Gardener's Dictionary of 1724 also refers to a "sprout cauliflower" and "Italian asparagus" (Gray, 1982). Vilmorin-Andrieux (1885) also describes "Purple Sprouting" or "Asparagus Broccoli." The crop may be much older; Buck (1956) proposes that the terms "asparagus broccoli," "sprouting broccoli," and "Christmas Calabrian broccoli" are synonymous with the "Bruttium broccoli" described by the naturalist Pliny, who lived in Italy from in the first century CE.

Until recently, purple and white WSB cultivars were primarily maintained by mass selection and were thus highly variable and considered unworked crops (Gray, 1982). Crisp and Gray (1985) characterized WSB as widely popular with amateur

\begin{tabular}{llll}
\hline $\begin{array}{l}\text { Units } \\
\text { To convert U.S. to SI, } \\
\text { multiply by }\end{array}$ & U.S. unit & SI unit & $\begin{array}{l}\text { To convert SI to U.S., } \\
\text { multiply by }\end{array}$ \\
\hline 0.3048 & $\mathrm{ft}$ & $\mathrm{m}$ & 3.2808 \\
2.54 & inch $(\mathrm{es})$ & $\mathrm{cm}$ & 0.3937 \\
4.8824 & $\mathrm{lb} / \mathrm{ft}^{2}$ & $\mathrm{~kg} \cdot \mathrm{m}^{-2}$ & 0.2048 \\
0.0254 & $\mathrm{mil}$ & $\mathrm{mm}$ & 39.3701 \\
28.3495 & $\mathrm{oz}$ & $\mathrm{g}$ & 0.0353 \\
305.1517 & $\mathrm{Oz} / \mathrm{ft}^{2}$ & $\mathrm{~g} \cdot \mathrm{m}^{-2}$ & 0.0033 \\
33.9057 & $\mathrm{oz} / \mathrm{yard}^{2}$ & $\mathrm{~g} \cdot \mathrm{m}^{-2}$ & 0.0295 \\
$\left({ }^{\circ} \mathrm{F}-32\right) \div 1.8$ & ${ }^{\circ} \mathrm{F}$ & ${ }^{\circ} \mathrm{C}$ & $\left(1.8 \times{ }^{\circ} \mathrm{C}\right)+32$ \\
& & &
\end{tabular}


growers and easy to grow but unpopular with commercial growers because of poor uniformity, inconsistent maturity time, and overall quality of the marketed product thus resulting in high harvest costs. However, WSB received high market prices because of popularity with consumers. Crisp and Gray (1985) also noted a short harvest season and observed that time to maturity is largely governed by temperature. This caused harvest to be sporadic in March and early April building to a peak in late April to May and then ceasing abruptly. These were considered poor conditions for marketing and also difficult conditions for maintaining consumer interest. In a response, breeding programs were undertaken to improve biennial sprouting broccoli (Crisp and Gray, 1985; Crisp et al., 1985; Gray, 1982).

Crisp and Gray (1985) acknowledge three categories of WSB: purplesprouting, early maturing white-sprouting, and late-maturing white-sprouting. According to Gray (1989), purple and early white WSB cultivars are classified as broccoli (B. oleracea var. italica) and late white WSB cultivars, with their relatively undifferentiated flower buds, are classified as cauliflower (B. oleracea var. botrytis). The purple-sprouting cultivars bore tight purple florets and early white-sprouting cultivars bore small loose clusters of pale yellow or pale green flower buds on long fleshy side shoots. The late-maturing white-sprouting cultivars were morphologically homogenous with short leafy side shoots bearing small compact white curds. The purple and early white cultivars were found to be broadly similar, with late white cultivars distinguished by later maturity and greater yield per plot (Crisp et al., 1985).

The improved genotypes selected by Crisp and Gray (1985) were released to Elsoms Seeds (Spalding, UK) and Tozers Seeds (Cobham, UK), two major commercial seed providers in England (D. Pink, personal communication). Elsoms Seeds currently maintains a breeding program as a joint venture with Bejo Zaden of Warmenhuizen, The Netherlands (Elsoms Seeds, 2008) and $\mathrm{F}_{1}$ hybrids are currently available. A limited number of these are currently commercially available in the United States; however, we are aware of no published research that addresses production of this crop in the United States.

Most of the United Kingdom has average annual minimum temperatures ranging from -10 to $-5{ }^{\circ} \mathrm{C}$, which corresponds to U.S. Department of Agriculture (USDA) USDA hardiness zones 8a-9a (Rice, 2010). In comparison, much of the northeastern United States falls within hardiness zones $3 \mathrm{a}-7 \mathrm{~b}$. It is reasonable to assume that season extension techniques might be required to overwinter the crop in New England, but the extent of protection required is unknown. The use of high or low tunnels covered with plastics, spunbonded, or woven rowcovers, or a combination thereof, are known to moderate harsh winter climates without supplemental heating (C.A. Martin and R.G. Sideman, unpublished; Lamont, 1996; Lamont et al., 2003; Takeda et al., 2008; Wells, 1996; Wien, 2009). We hypothesized that the use of high tunnels, with or without supplemental low tunnels, would permit WSB to survive the harsh New England winters to produce spring crops.

In 2006-07 and 2007-08, several WSB cultivars were transplanted into unheated high tunnels with and without supplemental rowcover in Durham, NH. Results from these pilot experiments suggested that factors such as rowcover, planting date, and cultivar affected yield, time to maturity, and the length of harvest season. High levels of mortality were observed for WSB plants grown in high tunnels without supplemental rowcover, suggesting that additional protection inside a high tunnel would be needed (R.G. Sideman, unpublished). In this manuscript, we report the results of subsequent experiments aiming to identify cultivars and cultural practices suitable for producing WSB in New England winter conditions. Specifically, we sought to evaluate cultivars currently available in England to determine comparative yields when grown overwinter in an unheated high tunnel in Durham, NH. In addition, use of secondary low tunnels within the high tunnel was examined for effect on yield, duration of harvest, and the number of days to harvest.

\section{Materials and methods}

Cultivars/germplasm. WSB cultivars were grown over two seasons for evaluation as a marketable spring crop. Five purple and five white WSB cultivars, and one green annual broccoli cultivar were compared. Biennial sprouting broccoli cultivars were selected on the basis of commercial availability. Purple-sprouting cultivars included Bordeaux and Santee (High Mowing Seeds, Wolcott, VT); and Claret, Red Head, and Red Spear (Elsoms Seeds). White-sprouting cultivars included Burbank, Colusa, and Late White Star (Elsoms Seeds); and Ninestar and White Sprouting Early (Thompson and Morgan Seeds, Lawrenceburg, IN). The annual green broccoli cultivar DeCicco (Johnny's Selected Seeds, Albion, ME) also was included in the 2008-09 experiment for comparison.

Location/Climate. Experiments were conducted in Durham $\mathrm{NH}$ (lat. $43.1^{\circ} \mathrm{N}$, long. $-70.9^{\circ} \mathrm{W}$ ) at the New Hampshire Agricultural Experiment Station. Durham is in USDA hardiness zone 5b (USDA, 2012), which corresponds to an average annual minimum temperature of -10 to $-15^{\circ} \mathrm{F}$.

High tunnel environment AND CUltural PRACTICES. Experiments were conducted in a $30 \times 60-\mathrm{ft}$ gothic-style unheated high tunnel with manual roll-up sides, and automatic ventilation fans (Ledgewood Farm Greenhouses, Moultonborough, $\mathrm{NH})$. The tunnel was covered with one layer of 4-year 6-mil infrared retaining (IR) plastic (K50-IR; Klerk's Plastic Products Manufacturing, Richburg, $\mathrm{SC})$. One ventilation fan was set to operate when the interior temperature reached $70{ }^{\circ} \mathrm{F}$ and a second fan was set to operate at $75^{\circ} \mathrm{F}$. In response to feedback from experienced winter growers and the observation that high temperatures of $75^{\circ} \mathrm{F}$ were reached frequently in the early spring, the fan activation temperatures were lowered to 60 and $65^{\circ} \mathrm{F}$, respectively, in the second year of our trial.

Fertilizers were applied according to commercial recommendations for broccoli based on annual soil tests. In the first year, $94 \mathrm{~g} \cdot \mathrm{m}^{-2}$ of $5 \mathrm{~N}-$ 1.3P-4.2K (Pro-Gro, North Country Organics, Bradford, VT) was applied to the tunnel before bed preparation. In the second year, the same rate of fertilizer and $224 \mathrm{~g} \cdot \mathrm{m}^{-2}$ of lime were applied to the tunnel. Each season, seven 18-inch-wide unmulched raised beds were formed lengthwise in the high tunnel with $4 \mathrm{ft}$ between row centers. 
Plants were seeded in 128-cell trays on 2 Sept. 2008 for Spring 2009 harvest and 19 Aug. 2009 for Spring 2010 harvest. Seeds were germinated in a climate controlled greenhouse and seedlings were transplanted 4 weeks later (30 Sept. 2008 and 16 Sept. 2009) into a staggered double row on raised beds with 9 inches between rows and 14 inches between plants within a row. After transplanting, trickle irrigation was supplied as needed by a frost-free hydrant and beds were hand-weeded as needed throughout the fall. Foliar applications of Bacillus thuringiensis (Dipel; Valent Biosciences, Libertyville, IL) were applied once at label rates to control caterpillars detected during scouting in Sept. 2008.

Because supplemental rowcover inside the larger high tunnel appeared to increase winter survival of plants during preliminary experiments, it was used on all plots in the cultivar trial. One layer of $1.25 \mathrm{oz} / \mathrm{yard}^{2}$ rowcover (Dupont 5131; Dupont, Wilmington, DE) was applied to plant beds using wire hoops and wooden stakes to create $\approx 2$-ft-high low tunnels that elevated the rowcover from the plant canopy (Fig. 1). Rowcover was applied in the late fall, when nighttime temperatures consistently fell below freezing (21 Nov. 2008 and 18 Nov. 2009), and was removed when harvest began in mid-March of both years.

Temperature monitoring. Soil and air temperature were collected within the tunnel and low tunnels using TMC6-HD thermocouples connected to Hobo U12-008 fourchannel outdoor data loggers (Onset Computer Corporation, Bourne, MA). Temperatures were logged at $15-\mathrm{min}$ intervals. Air temperature probes were shielded from sunlight and placed $15 \mathrm{~cm}$ above the soil surface. Soil temperature was recorded at a depth of $10 \mathrm{~cm}$ in the center of raised beds. Outdoor temperature data were collected using a $\mathrm{HOBO}{ }^{\circledR} \mathrm{H} 21-001$ Weather Station (Onset Computer Corp.) located $\approx 75 \mathrm{~m}$ from the high tunnel at the same elevation as the tunnel.

ExPERIMENTAL DESIGNS. The cultivar trial experimental design was completely random with four replications of 11 cultivars (2008-09) and 9 cultivars (2009-10). There were seven plants per experimental unit. In a separate experiment during the 2008-09 growing season, six cultivars (Bordeaux,

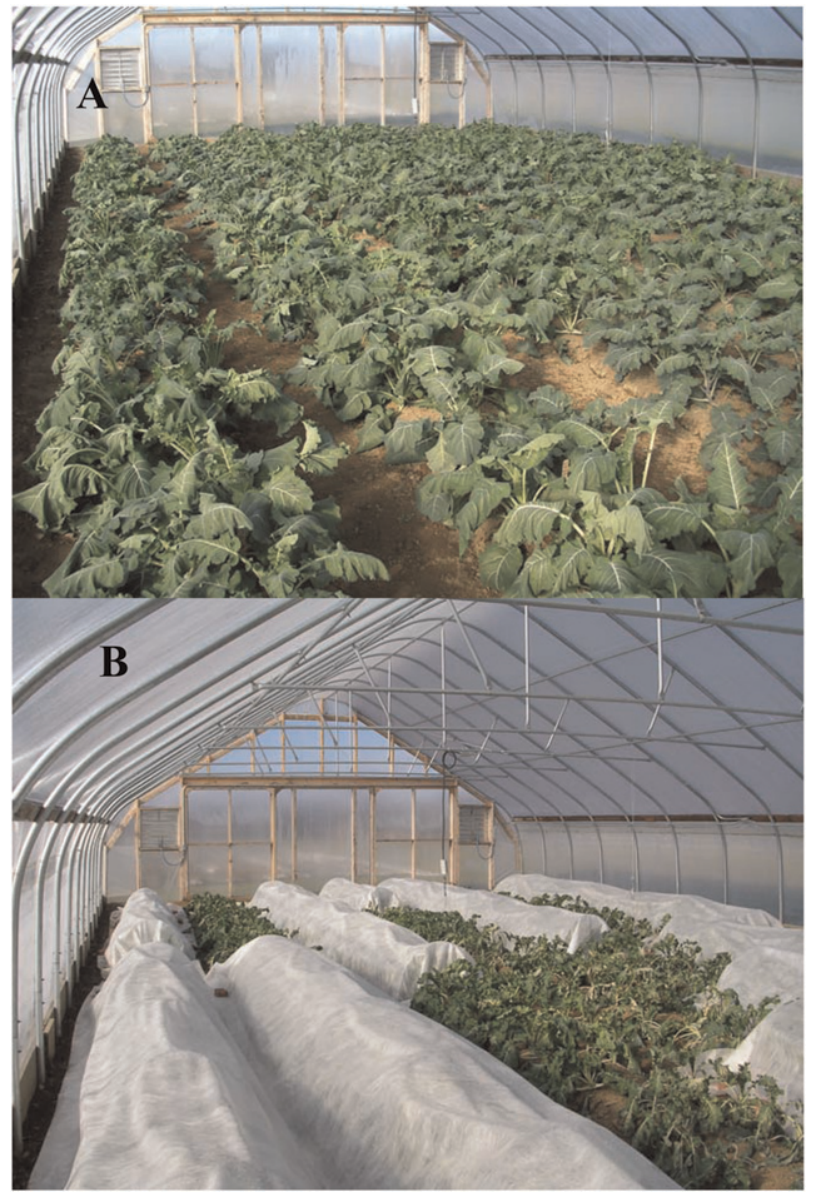

Fig. 1. Winter sprouting broccoli plants in a high tunnel on (A) 18 Nov. 2008 and (B) $12 \mathrm{Dec} .2008$ after supplemental rowcover was applied to selected plots.

Claret, Red Head, Red Spear, Santee, and DeCicco) were grown with and without supplemental rowcover, to quantify the effects of the rowcover on winter survival and spring yields. Rowcover treatments were also applied in a completely randomized design with four replications and experimental units of seven plants. Uncovered plants were cultivated and harvested identically to covered treatments. Because of space limitations, all seven beds, including edge and interior rows, were used for the experimental layout in both growing seasons. To minimize any potential edge effects, we were careful to exclude randomizations in which treatments were unevenly assigned to edge plots.

Data COLleCtion AND ANALYSIS. The following data were collected from each plot: harvested yield, time elapsed from seed sowing to first harvest (days to harvest), and harvest duration (days between first harvest to final harvest). The number of dead plants was recorded to establish percent mortality for each plot at the start of each year's harvest. While yield data were collected on a per-plot basis, yield data are presented on a per-plant basis, calculated based on experimental units of seven plants. This caused reported yields to be slightly lower than if per-plant yields were calculated on surviving plants only. Plants were observed throughout the winter and harvest period to assess desirable and undesirable characteristics of each cultivar.

All marketable shoots were harvested twice per week from March to May. Shoots considered marketable were floral shoots bearing closed but differentiating buds; these ranged from $\approx 10-20 \mathrm{~cm}$ in length. Florets on terminal shoots, which in some cases measured up to $10 \mathrm{~cm}$ across, were harvested and combined with lateral shoots. Leaves were left on the shoot and considered part of the marketable weight. Lateral stems and shoots that did not snap off easily by hand were 
considered too tough and were not

Multivariate correlation analysis was used to evaluate relationships between the dependent variables yield, days to harvest, and harvest duration. The effects of cultivar on these dependent variables were analyzed by analysis of variance (ANOVA) using JMP 8 (SAS Institute, Cary, NC). Frequency data showing mortality were arcsine-transformed before performing ANOVA. When the overall $\mathrm{F}$ test was significant $(P \leq 0.05)$, differences between treatments were evaluated using Tukey's honestly significant difference tests at the $P \leq 0.05$ level.

\section{Results}

Plant survival and The EFFECTS OF ROWCOVER. In general, winter temperatures in 2008-09 were colder (with an average temperature of -7.3 and $-2.4{ }^{\circ} \mathrm{C}$ in January and February, respectively) than 2009-10 (with an average temperature of -3.6 and $-1.0^{\circ} \mathrm{C}$ in January and February, respectively) (Table 1). Average temperatures measured in both years were similar to the 30-year average temperatures $\left(-4.8{ }^{\circ} \mathrm{C}\right.$ in January, $-3.1{ }^{\circ} \mathrm{C}$ in February) for Durham, $\mathrm{NH}$. The minimum temperatures in both the high tunnel and the supplemental rowcover within the high tunnel were much higher than outdoor temperatures. The lowest outdoor temperature in $2008-09$ was $-28.1^{\circ} \mathrm{C}$ on 16 Jan. 2009; concurrently the temperature inside the tunnel was $-16.6^{\circ} \mathrm{C}$ and the temperature under rowcover within the tunnel was $-11.2^{\circ} \mathrm{C}$. In 2009-10, the lowest temperature outdoors, within the tunnel, and under rowcover within the tunnel were $-19.1,-10.7$, and $-10.2{ }^{\circ} \mathrm{C}$, respectively, on 30 Jan. 2010.

While some cultivars experienced plant mortality during Winter 2008counted as part of the marketable yield.

09, all survived Winter 2009-10 (Table 2). In 2008-09, rowcovers reduced plant mortality for all cultivars tested (Table 2). For the six cultivars that were used to specifically evaluate the effects of rowcover, rowcover significantly reduced plant mortality, increased plant yield, and reduced days to harvest maturity (Table 3).

Among the covered plots, no significant differences in percent mortality were evident among cultivars. This may have been due, in part, to low sample numbers. However, it is noteworthy that mortality of whitesprouting cultivars averaged just $2.4 \%$, whereas mortality of purple cultivars averaged $12.4 \%$.

Mortality was higher in the uncovered plots $(28 \%$ to $89 \%)$ than covered plots ( $0 \%$ to $22 \%)$. Among the six cultivars grown in uncovered plots, the annual cultivar DeCicco had the highest mortality (89\%). In comparison with 'DeCicco', the cultivars Red Spear and Claret had significantly less mortality $(28 \%$ and $47 \%$, respectively). There were no significant differences between the five purple cultivars.

YIELD. Cumulative, season-long yield ranged from $\approx 150 \mathrm{~g} /$ plant to over $325 \mathrm{~g} /$ plant (Table 4). Yield averaged $248.6 \mathrm{~g} /$ plant in 2008-09, and $220.1 \mathrm{~g} /$ plant in 2009-10. While mean yields were higher in 2008-09 than in 2009-10, the differences were not statistically significant $(P=0.055)$, and the cultivar $\times$ year interaction was not significant. Within each year, there were few (2008-09) or no (2009-10) significant differences in yield between cultivars (Table 3). However, combined over both years, the two lowest yielding cultivars, Claret and Red Head, had significantly lower yields than the four highest yielding cultivars (Burbank, White Sprouting Early,

Table 1. Monthly temperature ranges in Durham, NH throughout the duration of Fall and Winter 2008-09 and 2009-10.

\begin{tabular}{llrrrrrrrr}
\hline & Sept. & Oct. & Nov. & Dec. & Jan. & Feb. & Mar. & Apr. \\
\hline $2008-09$ & Minimum $\left({ }^{\circ} \mathrm{C}\right)^{\mathrm{z}}$ & 0.8 & -4.6 & -10.0 & -14.9 & -28.1 & -20.0 & -15.2 & -3.3 \\
& Maximum $\left({ }^{\circ} \mathrm{C}\right)$ & 30.4 & 24.2 & 19.4 & 14.1 & 3.5 & 15.3 & 15.5 & 33.7 \\
& Average $\left({ }^{\circ} \mathrm{C}\right)$ & 16.0 & 9.0 & 6.1 & -3.2 & -7.3 & -2.4 & 1.1 & 8.8 \\
$2009-10$ & Minimum $\left({ }^{\circ} \mathrm{C}\right)$ & 1.4 & -2.6 & -5.1 & -15.9 & -19.1 & -12.0 & -7.4 & -2.2 \\
& Maximum $\left({ }^{\circ} \mathrm{C}\right)$ & 27.2 & 21.7 & 20.0 & 19.3 & 10.3 & 8.7 & 21.1 & 30.0 \\
& Average $\left({ }^{\circ} \mathrm{C}\right)$ & 15.0 & 8.4 & 6.6 & -2.2 & -3.6 & -1.0 & 5.0 & 10.2 \\
30 -year average $\left({ }^{\circ} \mathrm{C}\right)^{\mathrm{y}}$ & 16.0 & 9.9 & 4.2 & -1.8 & -4.8 & -3.1 & 1.5 & 7.6 \\
\hline
\end{tabular}

${ }^{\mathrm{z}}\left(1.8 \times{ }^{\circ} \mathrm{C}\right)+32={ }^{\circ} \mathrm{F}$.

${ }^{y}$ U.S. Department of Commerce (2004).
Late White Star, and Red Spear). In 2009-10, and overall, white-sprouting cultivars produced significantly higher yields than purple-sprouting cultivars $(P \leq 0.01)$.

DAYS TO HARVEST MATURITY. The earliest cultivars were first harvested in mid-March, and the latest cultivars were first harvested in early April. Time elapsed to first harvest varied with both year and cultivar (Table 5). The mean growth period in 2008-09 was $208.4 \mathrm{~d}$ and in 200910 was $233.8 \mathrm{~d}$. Most cultivars were harvested between 12 and $17 \mathrm{~d}$ later in 2010 than in 2009 with the exception of 'Ninestar' (22.5 d later) and 'Santee' (8.7 d later).

The relative days to maturity between cultivars were consistent from season to season, and the cultivar $x$ year interaction was not statistically significant. Over both seasons, the cultivars White Sprouting Early, Santee, and Red Spear matured earliest; and the cultivars Claret, Late White Star, and Ninestar were latest to mature. 'DeCicco' and 'Bordeaux', the earliest cultivars in the first year, were not included in the second year because of low shoot quality (DeCicco) and lack of availability (Bordeaux). As a group, the white-sprouting cultivars required more time to reach harvest maturity than purple-sprouting cultivars $(P<0.05)$.

Duration of harvest Period. All plants were harvested at least once, and some produced secondary and tertiary shoots for later harvests. Duration of harvest was influenced by an interaction between year and cultivar $(P<0.05)$. The time from first to last harvest ranged from 21.5 to $40.7 \mathrm{~d}$ with a standard error of 2.9. Most cultivars had similar harvest durations in both years while two cultivars (Red Spear and White Sprouting Early) were harvested for a significantly shorter period of time in 2010 than in 2009 (Fig. 2).

A multivariate correlation analysis between harvest duration and time from seed to harvest was negative in 2008-09 $(r=-0.9194)$ and 2009-10 $(r=-0.4393)$ and highly significant both years $(P<0.0001$ and $P<$ 0.0074 , respectively). This shows that, as the number of days from seed to harvest increases, the harvest period shortens. The correlation between harvest duration and yield and that between days to harvest and yield were weak. 
Table 2. Mortality of winter sprouting broccoli cultivars measured two consecutive years in mid-March after overwintering in a high tunnel with and without the protection of supplemental rowcovers.

\begin{tabular}{|c|c|c|c|c|}
\hline \multirow[b]{2}{*}{ Cultivar } & \multirow{2}{*}{$\begin{array}{l}\text { Shoot } \\
\text { Color }\end{array}$} & \multicolumn{2}{|c|}{ Mortality 2008-09 (\%) } & \multirow{2}{*}{$\frac{\text { Mortality 2009-10 (\%) }}{\text { Covered }}$} \\
\hline & & Covered $^{\mathrm{y}}$ & Uncovered & \\
\hline Burbank & White & 4 & $-^{x}$ & 0 \\
\hline Colusa & White & 4 & - & 0 \\
\hline Late White Star & White & 4 & - & 0 \\
\hline Ninestar & White & 0 & - & 0 \\
\hline $\begin{array}{l}\text { White Sprouting } \\
\text { Early }\end{array}$ & White & 0 & - & 0 \\
\hline Bordeaux & Purple & 11 & $57 \mathrm{ab}^{\mathrm{w}}$ & 0 \\
\hline Claret & Purple & 11 & $47 \mathrm{~b}$ & 0 \\
\hline Red Head & Purple & 22 & $75 \mathrm{ab}$ & 0 \\
\hline Red Spear & Purple & 0 & $28 \mathrm{~b}$ & 0 \\
\hline Santee (BE2778) & Purple & 11 & $75 \mathrm{ab}$ & 0 \\
\hline Decicco & Green & 7 & $89 \mathrm{a}$ & 0 \\
\hline$P$ value (F test) & & 0.1290 & 0.0037 & \\
\hline
\end{tabular}

${ }^{\mathrm{z}}$ Rowcover comparisons occurred in 2008-09 only.

${ }^{y}$ Covered plots were covered from late November through mid-March with $1.25-\mathrm{oz} / \mathrm{yard}^{2}\left(42.382 \mathrm{~g} \cdot \mathrm{m}^{-2}\right)$ rowcover.

${ }^{x}$ Not included in the rowcover comparison.

"Mortality means within columns followed by the same letter are not significantly different at $P \leq 0.05$ using

Tukey's honestly significant difference test.

Table 3. Winter sprouting broccoli response to supplemental rowcover application from mid-Nov. 2008 to mid-Mar. 2009 in an unheated high tunnel.

\begin{tabular}{lccr}
\hline Treatment & $\begin{array}{c}\text { Mortality } \\
{[\text { mean } \pm \text { SE }(\%)]}\end{array}$ & $\begin{array}{c}\text { Total yield } \\
{[\text { mean } \pm \text { SE }(\mathrm{g} / \text { plant })]^{\mathrm{z}}}\end{array}$ & $\begin{array}{r}\text { Time to maturity } \\
{[\text { mean } \pm \text { SE }(\mathrm{d})]}\end{array}$ \\
\hline Covered $^{\mathrm{y}}$ & $12.2 \pm 4.2$ & $206.5 \pm 10.7$ & $202.0 \pm 1.6$ \\
Uncovered & $74.4 \pm 4.2$ & $61.4 \pm 11.0$ & $218.7 \pm 1.7$ \\
$P$ value & $<0.0001$ & $<0.0001$ & $<0.0001$ \\
\hline
\end{tabular}

${ }^{\mathrm{z}} \mathrm{lg}=0.0353 \mathrm{oz}$.

${ }^{y}$ Covered plots were covered from late November to mid-March with $1.25-\mathrm{oz} / \mathrm{yard}^{2}\left(42.382 \mathrm{~g} \cdot \mathrm{m}^{-2}\right)$ rowcover.

Table 4. Season-long yields of winter sprouting broccoli measured two consecutive years in mid-March after overwintering in high tunnels with the protection of supplemental rowcovers.

\begin{tabular}{|c|c|c|c|c|}
\hline \multirow[b]{2}{*}{ Cultivar } & \multirow{2}{*}{$\begin{array}{l}\text { Shoot } \\
\text { color }\end{array}$} & \multicolumn{3}{|c|}{ Mean season-long yield (g/plant $)^{\mathrm{z}}$} \\
\hline & & $2008-09$ & $2009-10$ & Overall \\
\hline Burbank & White & $277.2 \mathrm{ab}^{\mathrm{y}}$ & $276.9 \mathrm{a}$ & $277.1 \mathrm{a}$ \\
\hline Colusa & White & $292.8 \mathrm{ab}$ & $188.4 \mathrm{a}$ & $240.6 \mathrm{ab}$ \\
\hline Late White Star & White & $261.2 \mathrm{ab}$ & $273.1 \mathrm{a}$ & $267.1 \mathrm{a}$ \\
\hline Ninestar & White & $238.5 \mathrm{ab}$ & 207.9 a & $223.2 \mathrm{ab}$ \\
\hline White Sprouting Early & White & $328.4 \mathrm{a}$ & $214.7 \mathrm{a}$ & $271.5 \mathrm{a}$ \\
\hline Bordeaux & Purple & $186.2 \mathrm{ab}$ & $\mathrm{NA}^{\mathrm{x}}$ & NA \\
\hline Claret & Purple & $170.6 \mathrm{ab}$ & $153.5 \mathrm{a}$ & $162.1 \mathrm{~b}$ \\
\hline Red Head & Purple & $151.3 \mathrm{~b}$ & $161.5 \mathrm{a}$ & $156.4 \mathrm{~b}$ \\
\hline Red Spear & Purple & $292.9 \mathrm{ab}$ & $232.3 \mathrm{a}$ & $262.6 \mathrm{a}$ \\
\hline Santee & Purple & $224.9 \mathrm{ab}$ & $272.4 \mathrm{a}$ & $248.7 \mathrm{ab}$ \\
\hline DeCicco & Green & $213.1 \mathrm{ab}$ & NA & NA \\
\hline $\begin{array}{l}\text { Experiment } \\
\text { mean } \pm S E\end{array}$ & & $248.6 \pm 34.8$ & $220.1 \pm 27.1$ & $234.4 \pm 21.8$ \\
\hline Analysis of variance & & & $P$ value & \\
\hline Cultivar & & 0.0179 & 0.1136 & 0.0004 \\
\hline Year & & - & - & 0.0547 \\
\hline Cultivar $\times$ year & & - & - & 0.1569 \\
\hline Contrast (White vs. Purple) & & 0.0019 & 0.1450 & 0.0017 \\
\hline
\end{tabular}

${ }^{\mathrm{z}} \mathrm{lg}=0.0353 \mathrm{oz}$.

yYield means within columns followed by the same letter are not significantly different at $P \leq 0.05$ using Tukey's honestly significant difference test.

${ }^{x}$ Not included in the experiment.
Cultivar characteristics. Length of marketable spears ranged from $\approx 8$ to $25 \mathrm{~cm}$, with most $13-20 \mathrm{~cm}$. Spears were harvested before buds on floral shoots began to enlarge and open (Fig. 3). Most of the spears were secondary shoots (arising from the primary stem). Tertiary shoots, which arose from the leaf nodes of secondary shoots, were generally smaller, but harvestable 3-4 d after the secondary shoots were cut. Most shoots were tender and readily snapped off by hand; however some were difficult to break, tough and stringy, and therefore considered unmarketable. Tertiary shoots, and shoots harvested later in the harvest season, were more likely to be tough. The cultivar Claret exhibited tough tissues throughout the experiment, resulting in comparatively low yields in the cultivar experiment.

Purple-sprouting broccoli inflorescences ranged from purplish green to shades of bright purple. Those of white-sprouting cultivars ranged from pale green (White Sprouting Early) to creamy yellow (Colusa). The cultivar Burbank exhibited pale yellow sprouts with a purpling tint that developed as the buds matured, which gave the undesirable impression of necrosis in the inflorescence. This discoloration was also present to a lesser degree in 'Colusa', but was generally absent from the cultivars White Sprouting Early, Ninestar, and Late White Star.

All of the purple cultivars had fully differentiating buds, like heading broccoli. Inflorescences on whitesprouting cultivars frequently were smaller in diameter than on purplesprouting cultivars; and, while some cultivars had differentiating buds (White Sprouting Early, Colusa) others consisted of undifferentiated curds (Burbank, Ninestar, Late White Star).

While the annual green sprouting cultivar DeCicco showed overwinter survival equivalent to the biennial WSB cultivars (when grown under supplemental rowcover), its shoots were of inferior quality. Shoots were very thin (often $<0.5 \mathrm{~cm}$ diameter) with tough flesh and florets were much less compact and opened more quickly than other cultivars.

Characteristics such as plant height and leaf shape varied within and between cultivars (anecdotal). Some cultivars had shoots that consisted primarily of long stems with a terminal inflorescence and very few leaves 
Table 5. Days to maturity of winter sprouting broccoli cultivars planted on 2 Sept. 2008 and 19 Aug. 2009 and overwintered under supplemental rowcovers for harvests in Spring 2009 and 2010, respectively.

\begin{tabular}{lcccc}
\hline & Shoot & \multicolumn{3}{c}{ Mean time from seed to first harvest (d) } \\
\cline { 3 - 5 } Cultivar & color & $\mathbf{2 0 0 8 - 0 9}$ & $\mathbf{2 0 0 9 - 1 0}$ & Overall \\
\hline Burbank & White & $208.3 \mathrm{ab}^{\mathrm{z}}$ & $226.0 \mathrm{bcd}$ & $217.1 \mathrm{bcd}$ \\
Colusa & White & $206.3 \mathrm{ab}$ & $222.5 \mathrm{~cd}$ & $214.4 \mathrm{de}$ \\
Late White Star & White & $216.8 \mathrm{a}$ & $232.5 \mathrm{ab}$ & $224.6 \mathrm{ab}$ \\
Ninestar & White & $216.0 \mathrm{a}$ & $238.5 \mathrm{a}$ & $227.3 \mathrm{a}$ \\
White Sprouting Early & White & $202.8 \mathrm{abc}$ & $220.0 \mathrm{de}$ & $211.4 \mathrm{def}$ \\
Bordeaux & Purple & $196.5 \mathrm{bc}$ & $\mathrm{NA}^{\mathrm{y}}$ & $\mathrm{NA}$ \\
Claret & Purple & $217.0 \mathrm{a}$ & $229.0 \mathrm{bc}$ & $223.0 \mathrm{abc}$ \\
Red Head & Purple & $208.5 \mathrm{ab}$ & $223.5 \mathrm{~cd}$ & $216.0 \mathrm{~cd}$ \\
Red Spear & Purple & $199.8 \mathrm{bc}$ & $213.5 \mathrm{ef}$ & $206.6 \mathrm{ef}$ \\
Santee & Purple & $200.3 \mathrm{bc}$ & $209.0 \mathrm{f}$ & $204.6 \mathrm{f}$ \\
DeCicco & Green & $190.0 \mathrm{c}$ & $\mathrm{NA}$ & $\mathrm{NA}$ \\
Experiment mean \pm SE & & $208.4 \pm 3.2$ & $223.8 \pm 1.5$ & $216.1 \pm 1.8$ \\
Analysis of variance & & & $P$ value & \\
Cultivar & & 0.0001 & 0.0001 & 0.0001 \\
Year & & - & - & 0.0001 \\
Cultivar $\times$ year & & 0.0086 & $<0.0001$ & $<0.0001$ \\
Contrast (White vs. Purple $)$ & &
\end{tabular}

${ }^{\text {"Yield means within columns followed by the same letter are not significantly different at } P \leq 0.05 \text { using Tukey's }}$ honestly significant difference test.

Not included in the experiment.

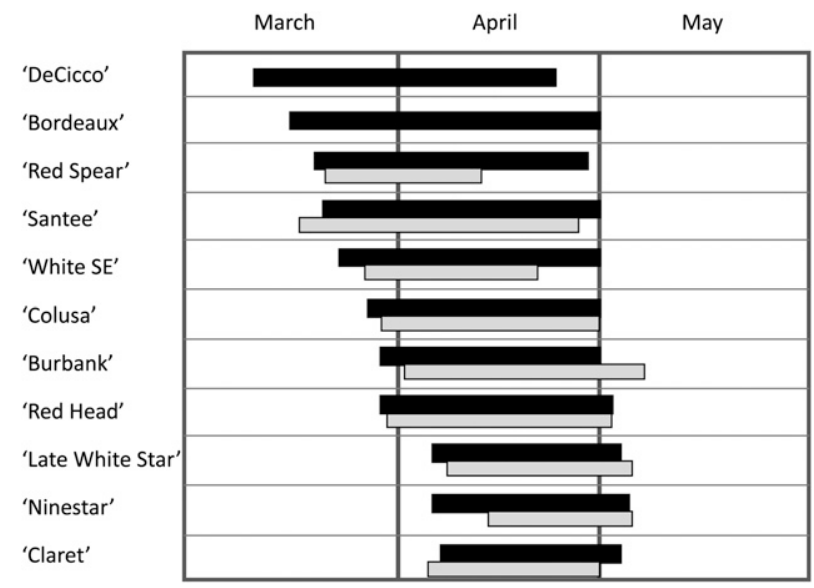

Fig. 2. Start of harvest and harvest duration of winter sprouting broccoli cultivars in Spring 2009 (black bars) and Spring 2010 (gray bars).

(Santee), while others had several leaf nodes on harvestable shoots (White Sprouting Early, Red Spear, Colusa, Burbank). The leaves of shoots were tender and edible and therefore considered part of the marketable product. In general, the white cultivars had longer sprouts with more leaves and smaller heads than the purple cultivars (Fig. 4).

FreEze INJURY AND WINTER DAMAGE. Stem and petiole splitting was widespread throughout most cultivars in 2008-09, but minimal stem splitting occurred in 2009-10. The cause of this injury is unknown, but it may have been related to increased plant vigor and freezing and thawing of water in the plant stems throughout the winter. The effects of stem splitting on plant yield were not specifically quantified, but it did not result in plant death. Visual observations indicated that splitting was equally present on uncovered and covered plants. In both seasons, the oldest leaves of all cultivars showed extensive necrosis and chlorosis, including cultivars under rowcover. We hypothesize that this damage was caused by freeze injury to the leaf lamina, consistent with previous observations (Tan et al., 1999). In general, freeze injury was less severe on covered compared with uncovered plants and was not present on new spring growth.

Necrotic leaf margins and necrotic spear tips were observed in some cultivars. This condition was particularly noticeable on the cultivars Burbank, Colusa, and White Sprouting Early, and resulted in unmarketable spears. Wells and Loy (1985) reported that foliage that is in contact with rowcovers is susceptible to frost damage. We hypothesize that this was caused either by freeze damage because of direct contact with rowcover or heat damage before rowcover removal.

Plant lodging, characterized by plant stems that grew on their "side" extending horizontally along the ground before curving up, was widespread in the experiments. Raising transplants in high temperature conditions of late August and September may have contributed to plant lodging. The effects of plant lodging on yield of WSB are unknown. Internode length varied during the experiment and plants within the same experimental unit exhibited visible differences. Occasional plants showed shortened internodes that contributed to a compact bush-like appearance with large numbers of spears that were difficult to harvest. It is not clear whether this is due to genetic or environmental factors.

\section{Discussion}

Our experiments established that fall plantings of WSB may be overwintered in an unheated high tunnel for spring harvest in USDA Hardiness Zone 5 sites. Regardless of cultivar, the additional winter protection offered by a supplemental layer of rowcover increased winter survival, yields and earliness. This is consistent with prior research demonstrating that rowcovers can be used to reduce winter injury and increase yields of overwintered perennial crops (Lamarre et al., 1992; Takeda et al., 2008).

In our experiments, the minimum winter temperatures reached within the unheated high tunnel and inside the low tunnel within the high tunnel were considerably higher than outdoor temperatures. Several researchers have shown that tunnel temperatures equalize with, and briefly 


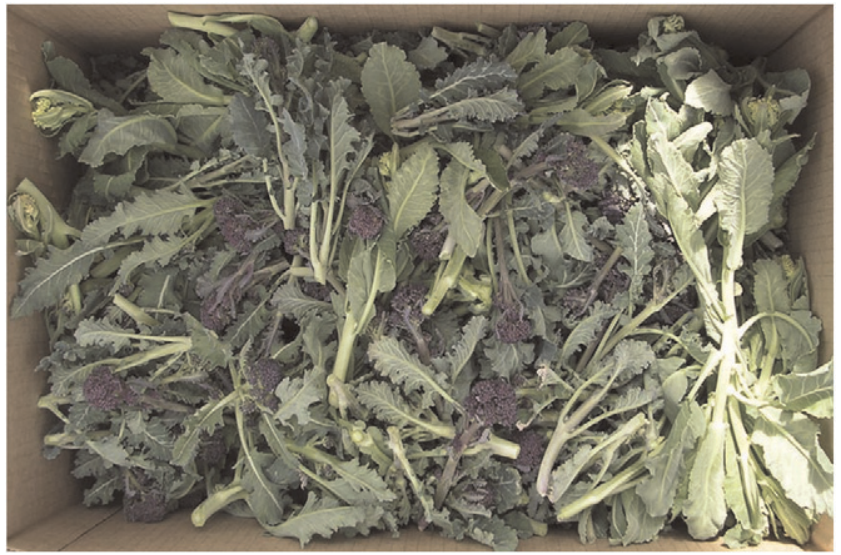

Fig. 3. The harvested portion of assorted cultivars of winter sprouting broccoli, showing shoots, florets, and attached leaves.

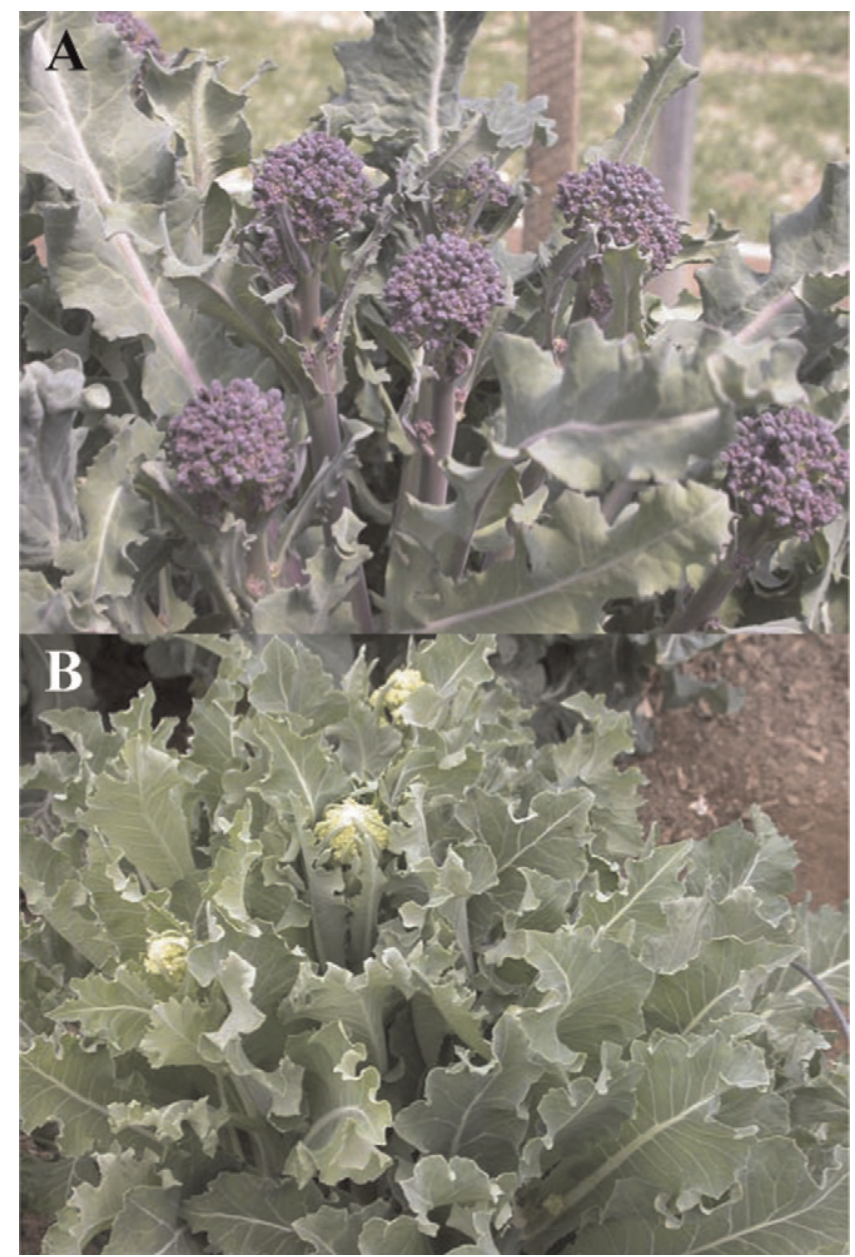

Fig. 4. The sprouting broccoli cultivars (A) Claret and (B) Ninestar at harvest maturity.

drop below, outdoor temperatures on cold nights (Baytorun et al., 1994; Montero et al., 1985; Wien 2009). In our work, this was occasionally observed at more moderate temperatures, but not at extremely low winter greenhouse coverings like that we used (Baytorun et al., 1994; Maia et al., 1990). Together, these may explain the high temperatures that we observed in unheated but protected environments, as compared with outdoors. The potential for overwintering this crop under other types of coverings and ventilation regimes is an area where additional research may be warranted.

Our results suggest that some cultivars are more suited to winter production in unheated high tunnels than others. 'Santee', 'Red Spear', 'White Sprouting Early' were among the highest yielding and exhibited desirable physical characteristics. Their harvested spears were attractive, tender, early maturing, and of ideal length. 'Claret' and 'Red Head' were low yielding, and while 'Colusa' and 'Burbank' exhibited high yields, they were susceptible to undesirable bud discoloration and tissue damage. 'Late White Star' offered potential to lengthen the duration of harvest as a later-maturing cultivar.

The 25-d difference in days to maturity between years may be due in part to the 13-d difference in fall seeding and transplanting dates, and may be due in part to typical seasonal variations in temperature and sunlight. A better understanding of the factors that impact maturity date and ability to predict harvest maturity are an area that would merit further research.

Overall, mean yields ranged from 156 to $277 \mathrm{~g} /$ plant, with an average of $234 \mathrm{~g} /$ plant. At our experimental spacing, this corresponds to a yield of $156 \mathrm{~g}(0.33 \mathrm{lb})$ per square foot of high tunnel space. This compares favorably to yields reported by Blomgren and Frisch (2007) for spinach (Spinacia oleracea) grown in unheated high tunnels in a similar climate $(0.39-$ $\left.0.59 \mathrm{lb} / \mathrm{ft}^{2}\right)$; however, WBS would inhabit high tunnel space for a longer period of time than fall-planted spinach, requiring a higher price per pound to produce equivalent profit for a given unit of time. The broccoli harvest would be complete by early May, which would permit the tunnel to be ready for early season tomatoes during the summer season, a primary use of high tunnels in the northeastern United States.

Additional research is needed to determine whether modification of cultural practices such as plant spacing, 
fertility management, high tunnel coverings, and timing of supplemental rowcover application and removal, could increase yields. While we found that local chefs and consumers responded very favorably to the crop produced in the experiments described in this paper, the market for this crop has not yet been developed in the United States, and growers would need to develop and cultivate a market for this niche crop.

\section{Literature cited}

Baytorun, N., K. Abak, H. Tokgoz, and O. Altuntas. 1994. Effect of different greenhouse covering materials on climate and on the development of tomato plants. Acta Hort. 366:125-132.

Blomgren, T. and T. Frisch. 2007. High tunnels: Using low-cost technology to increase yields, improve quality and extend the season. Univ. Vermont Ctr. Sustainable Agr., Burlington, VT.

Buck, P.A. 1956. Origin and taxonomy of broccoli. Econ. Bot. 10:250-253.

Cintas, N.A., S.T. Koike, and C.T. Bull. 2002. A new pathovar, Pseudomonas syringae pv. alisalensispv. nov., proposed for the causal agent of bacterial blight of broccoli and broccoli raab. Plant Dis. 86:992-998.

Crisp, P. and A.R. Gray. 1985. The genetic potential of biennial sprouting broccoli. Sci. Hort. 36:21-31.

Crisp, P., A.R. Gray, H. James, S.J. Ives, and S.M. Angell. 1985. Improving purple sprouting broccoli by breeding. J. Hort. Sci. 60:325-334.
Elsoms Seeds. 2008. Sprouting broccoli cropping guide. 16 Apr. $2012<$ http:// www.elsoms.com/organic-vegetables/ brassicas/sprouting-broccoli.aspx $>$.

Gray, A.R. 1982. Taxonomy and evolution of broccoli (Brassica oleracea var italica). Econ. Bot. 36:397-410.

Gray, A.R. 1989. Taxonomy and evolution of broccolis and cauliflowers. Baileya $23: 28-46$.

Lamarre, M., M.J. Lareau, and S. Payette. 1992. Influence des couvertures hivernale sur la productivité du fraisier au Québec. Can. J. Plant Sci. 72:299-305.

Lamont, W.J. 1996. What are the components of a plasticulture vegetable system? HortTechnology 6:150-154.

Lamont, W.J., M.D. Orzolek, E.J. Holcomb, K. Demchak, E. Burkhart, L. White, and B. Dye. 2003. Production system for horticultural crops grown in the Penn State high tunnel. HortTechnology 13:358362 .

Livingston, T. 2010. Broccolini ${ }^{\circledR}$ : What's in a name? Gastronomica 10:89-92.

Maia, M.B., A.A. Monteiro, and J.F. Meneses. 1990. The influence of two different polyethylene films on greenhouse minimum temperatures and on the growth and yield of a tomato crop. Acta Hort. 263:265-274.

Montero, J.I., N. Castilla, E. Gutierrez de Rave, and F. Bretones. 1985. Climate under plastic in the Almeria area. Acta Hort. 170:227-234.

Nieuwhof, M. 1969. Cole crops. Leonard Hill, London.
Rice, G. 2010. An international perspective on hardiness ratings. Plantsman (Lond., Engl.) 9:118-119.

Takeda, F., K. Demchak, M.R. Warmund, D.T. Handley, R. Grube, and C. Feldhake. 2008. Rowcovers improve winter survival and production of western trailing 'Siskiyou' blackberry and the eastern United States. HortTechnology 18:575-582.

Tan, D.K.Y., A.H. Wearing, K.G. Rickert, C.J. Birch, and D.C. Joyce. 1999. Freezeinduced reduction of broccoli yield and quality. Austral. J. Expt. Agr. 39:771780 .

Vilmorin-Andrieux, M.M. 1885. The vegetable garden. John Murray, London.

Wells, O.S. 1996. Rowcover and high tunnel growing systems in the United States. Hort Technology 6:172-176.

Wells, O.S. and J.B. Loy. 1985. Intensive vegetable production with row covers. HortScience 20:822-826.

Whealy, K. 2004. Garden seed inventory. Seed Savers Exchange Inc., Decorah IA.

Wien, H.C. 2009. Microenvironmental variations within the high tunnel. HortScience 44:235-238.

U.S. Department of Agriculture. 2012. USDA Plant Hardiness Zone Map. 16 Apr. 2012. <http://planthardiness.ars. usda.gov $/>$.

U.S. Department of Commerce. 2004. Climatography of the United States No. 20 1971-2000, COOP ID 272174, Durham, NH. 16 Apr. 2012. <http:// www.ncdc.noaa.gov/oa/climate/normals/ usnormalsprods.html>. 